\title{
News from the German Federal Republic
}

\author{
Courses and Seminars in the History of the \\ Habsburg Monarchy
}

During the summer of 1970 several courses and seminars on the history of the Habsburg monarchy were given in German universities. At the University of Göttingen, Hans Patze taught a two-hour lecture course on the history of Austria during the middle ages. Joseph Staber gave a onehour lecture course at the University of Regensburg which dealt with the history of the Church in the Bohemian lands during the nineteenth and twentieth centuries. At the University of Kiel, Hartmut Lehmann taught a two-hour lecture course on the nationality problems of Austria-Hungary between 1848 and 1918 and a two-hour seminar on problems of Austro-Hungarian foreign policy during the First World War.

During the winter semester of 1970-1971 an unusually large number of courses were devoted to problems of the Habsburg monarchy and the Austrian Republic. At the University of Bochum, Hans Roos gave a two-hour seminar on the origins of the states of East-Central Europe. At the University of Freiburg (Breisgau), Erich Hassinger taught both a two-hour lecture course on "The Fall of Austria-Hungary as a Historical Gesamtproblem (Army, Church, Society, Economy)" and a two-hour seminar on political and religious communities in Austria-Hungary, 1848-1918. At the University of Cologne, Hans Lemberg treated the main phases of Czechoslovakian history in a two-hour lecture course. At the University of Mainz, Georg Wild devoted a two-hour seminar to problems of Austrian colonization in the East and Southeast in the eighteenth and nineteenth centuries, and Konrad Fuchs handled Austrian economic problems during the time of the First Republic in another two-hour seminar. Jörg K. Hoensch gave a two-hour seminar on national movements and revolutions in East-Central Europe at the University of Tübingen, and Peter Baumgart devoted a two-hour seminar to the history of Prussia under Frederick II and of Austria under Maria Theresa and Joseph II at the University of Würzburg. 


\section{Meetings}

On February 28 and March 1, 1969, a two-day conference devoted to a discussion of "Social Structure and Problems of Organization of European National Movements" was held at the University of Cologne. The meeting was organized by the research section of the historical seminar of the University of Cologne, with the support of the Fritz Thyssen Foundation of Cologne. At this meeting Mirjana Gross, of Zagreb, spoke on the Croatian national movement and its relationship with Budapest and Vienna during the nineteenth and early part of the twentieth century.

Questions dealing with Austrian history were discussed at the twenty-eighth conference of German historians, which was held at Cologne on April 2-4, 1970. Heinrich Koller, of the University of Salzburg, spoke on imperial policies and reform plans during the fifteenth century. Karl Otmar von Aretin, of the University of Darmstadt, talked on Emperor Joseph I's imperial policies; and Hans Roos, of the University of Bochum, on East-Central Europe and the Great Powers during the peace negotiations of 1919 .

\section{Doctoral Dissertations}

Among the doctoral dissertations recently completed in German universities, the following are of special interest to students of Austrian history:

Kleinmann, Hans-Otto, Die Politik des Wiener Hofes gegenüber der spanischen Monarchie unter Karl III. 1759-1788. University of Cologne, 1967.

Löding, Dörte, Deutschlands und österreich-Ungarns Balkanpolitik von 1912-1914 unter besonderer Berïcksichtigung ihrer Wirtschaftsinteressen. University of Hamburg, 1969.

Puchta, Hans, Die Habsburgische Herrschaft in Württemberg 1520-1534. University of Munich, 1967. 